\title{
$\left[{ }^{11} \mathrm{C}\right] \mathrm{AF} 150(\mathrm{~S})$, an agonist PET ligand for M1 muscarinic acetylcholine receptors
}

Hans JC Buiter ${ }^{1 *}$, Albert D Windhorst ${ }^{1}$, Marc C Huisman ${ }^{1}$, Maqsood Yaqub ${ }^{1}$, Dirk L Knol ${ }^{2}$, Abraham Fisher ${ }^{3}$, Adriaan A Lammertsma ${ }^{1}$ and Josée E Leysen ${ }^{1}$

\begin{abstract}
Background: The M1 muscarinic acetylcholine receptor (M1ACh-R) is a G protein-coupled receptor that can occur in interconvertible coupled and uncoupled states. It is enriched in the basal ganglia, hippocampus, olfactory bulb, and cortical areas, and plays a role in motor and cognitive functions. Muscarinic M1 agonists are potential therapeutic agents for cognitive disorders. The aim of this study was to evaluate $\left[{ }^{11} \mathrm{C}\right] \mathrm{AF} 150(\mathrm{~S})$ as a putative M1ACh-R agonist PET ligand, which, owing to its agonist properties, could provide a tool to explore the active $G$ protein-coupled receptor.
\end{abstract}

Methods: Regional kinetics of $\left[{ }^{11} \mathrm{C}\right] \mathrm{AF} 150(\mathrm{~S})$ in rat brain were measured using a high-resolution research tomograph, both under baseline conditions and following pre-treatment with various compounds or coadministration of non-radioactive AF150(S). Data were analysed by calculating standard uptake values and by applying the simplified reference tissue model (SRTM).

Results: $\left[{ }^{11} \mathrm{C}\right] \mathrm{AF} 150(\mathrm{~S})$ was rapidly taken up in the brain, followed by a rapid clearance from all brain regions. Analysis of PET data using SRTM revealed a binding potential (BP ${ }_{\mathrm{ND}}$ ) of 0.25 for the striatum, 0.20 for the hippocampus, 0.16 for the frontal cortical area and 0.15 for the posterior cortical area, all regions rich in M1ACh-R. $\mathrm{BP}_{\mathrm{ND}}$ values were significantly reduced following pre-treatment with $\mathrm{M} 1 \mathrm{ACh}-\mathrm{R}$ antagonists. $\mathrm{BP}_{\mathrm{ND}}$ values were not affected by pre-treatment with a M3ACh-R antagonist. Moreover, $\mathrm{BP}_{\mathrm{ND}}$ was significantly reduced after pre-treatment with haloperidol, a dopamine $D_{2}$ receptor blocker that causes an increase in extracellular acetylcholine (ACh). The latter may compete with $\left[{ }^{11} \mathrm{C}\right] \mathrm{AF} 150$ (S) for binding to the M1ACh-R; further pharmacological agents were applied to investigate this possibility. Upon injection of the highest dose $\left(49.1 \mathrm{nmol} \mathrm{kg}{ }^{-1}\right)$ of $\left[{ }^{11} \mathrm{C}\right] \mathrm{AF} 150(\mathrm{~S})$ diluted with nonradioactive AF150(S), brain concentration of AF150(S) reached $100 \mathrm{nmol} \mathrm{L^{-1 }}$ at peak level. At this concentration, no sign of saturation in binding to M1ACh-R was observed.

Conclusions: The agonist PET ligand $\left[{ }^{11} \mathrm{C}\right] \mathrm{AF} 150(\mathrm{~S})$ was rapidly taken up in the brain and showed an apparent specific M1ACh-R-related signal in brain areas that are rich in M1ACh-R. Moreover, binding of the agonist PET ligand $\left[{ }^{11} \mathrm{C}\right] \mathrm{AF} 150(\mathrm{~S})$ appears to be sensitive to changes in extracellular ACh levels. Further studies are needed to evaluate the full potential of $\left[{ }^{11} \mathrm{C}\right] \mathrm{AF} 150(\mathrm{~S})$ for imaging the active pool of M1ACh-R in vivo.

Keywords: PET imaging, agonist, $\left[{ }^{11} \mathrm{C}\right] \mathrm{AF} 150(\mathrm{~S})$, G protein-coupled receptor, rat brain, M1 muscarinic acetylcholine receptor

\footnotetext{
* Correspondence: HJC.Buiter@vumc.nl

${ }^{1}$ Department of Nuclear Medicine \& PET Research, VU University Medical

Center, PO Box 7057, Amsterdam, 1007 MB, The Netherlands

Full list of author information is available at the end of the article
} 


\section{Background}

Acetylcholine (ACh) is a core neurotransmitter that controls vital functions via the peripheral nervous system (e.g. heart rate, intestinal motility, and glandular secretion) and the central nervous system (CNS) (e.g. cognitive and motor functions) [1]. Cholinergic neurotransmission is processed via nicotine and muscarinic acetylcholine receptors (MACh-R). The former are ligand-gated ion channels; the latter are metabotropic $G$ protein-coupled receptors (GPCRs). The MACh-R family comprises five characterised subtypes (M1 to M5) [2].

M1ACh- $\mathrm{R}$ is the most prevalent MACh-R subtype in the CNS and acts as an excitatory receptor that is coupled to the $G \alpha_{\mathrm{q} / 11}$ protein [3]. It is located primarily in postsynaptic nerve terminals in forebrain regions including the basal ganglia, hippocampus and cortical areas; the cerebellum is essentially devoid of M1ACh-R [4]. M1ACh-R in the forebrain regions play a role in motor control and cognition and is thought to be implicated in pathologies such as schizophrenia, Parkinson's disease and Alzheimer's disease [5,6]. Studies using M1ACh-R agonists in laboratory animals have shown improvement in cognitive functions [7]. Clinical studies in patients with Alzheimer's disease and schizophrenia revealed attenuation of psychotic behaviour and showed improvement of cognition [8].

A non-invasive molecular imaging technique such as positron emission tomography (PET) could be useful to elucidate the function of M1ACh-R in vivo. In the past, several compounds with affinity for M1ACh-R have been labelled with carbon-11, e.g. $\left[{ }^{11} \mathrm{C}\right]$ scopolamine, $\left[{ }^{11} \mathrm{C}\right] \mathrm{NMPB},\left[\mathrm{N}-{ }^{11} \mathrm{C}\right.$-methyl]-benztropine and $\left[{ }^{11} \mathrm{C}\right] \mathrm{QNB}$ [9-12]. These PET ligands demonstrated good brain uptake and allowed mapping of MACh-R in primate and human brains. However, these ligands are not M1ACh-R selective, and they show slow ligand-receptor dissociation kinetics, by which ligand-receptor binding equilibrium cannot be reached in vivo [13,14]. In addition, the above-mentioned radioligands are antagonists that bind to the total pool of GPCRs. Consequently, they cannot distinguish between activated GPCRs and uncoupled inactive receptors. In contrast, agonists usually show high affinity for $\mathrm{G}$ protein-coupled receptors and low affinity for uncoupled receptors. Therefore, at low concentrations, they bind to the activated receptors only. The occurrence of interconvertible affinity states of GPCRs has been amply documented [15] and was also demonstrated for M1ACh-R in in vitro experiments $[16,17]$. Studies with agonist PET ligands for the dopamine $\mathrm{D}_{2}$ receptor, such as $\left[{ }^{11} \mathrm{C}\right](+)$-PHNO, revealed that the agonist PET ligand labelled in vivo a smaller receptor pool than an antagonist PET ligand, and moreover, agonist PET ligands appeared more sensitive to displacement by released endogenous dopamine [18]. This can be taken as an indication that the agonist PET ligand preferentially labels the active $\mathrm{G}$ protein-coupled receptor pool, which is the target for the endogenous neurotransmitter.

Besides for the dopamine $D_{2}$ [19-22] and the $\mu$-opiate receptor [23], few agonist PET ligands have been investigated for other GPCRs. The tested muscarinic agonists, $\left[{ }^{11} \mathrm{C}\right]$ xanomeline and $\left[{ }^{11} \mathrm{C}\right]$ butylThio-TZTP, appeared not selective for the M1ACh-R subtype and show high binding affinity for $\sigma$ sites, leading to substantial nonselective binding. In addition, they suffer from poor pharmacokinetics [24].

In the search for a suitable selective M1ACh-R agonist PET ligand, AF150(S) was selected based on its pharmacological properties. AF150(S) has moderate affinity with an apparent equilibrium dissociation constant for highaffinity binding sites, $K_{\mathrm{d}, \mathrm{H}}=200 \mathrm{nM}$ for M1ACh-R in rat cerebral cortex and shows functional selectivity for M1ACh-R in transfected cells [25]. AF150(S) belongs to a series of selective M1ACh-R agonists related to cevimeline (AF102B) [26]. Cevimeline, a rigid analogue of ACh, is marketed for human medicinal use and is likely to act as an orthosteric agonist. The pharmacological and potential therapeutic properties of AF150(S) have been investigated extensively in animal models of neurological diseases, where improvement in cognitive functions, reduction of amyloid plaques and decrease in tau phosphorylation were demonstrated [27-29]. AF150 (S) and its congener AF267B have been considered as potential dual symptomatic and disease-modifying treatments for Alzheimer's disease [30]. Such important possible therapeutic application further supports the interest for investigating $\left[{ }^{11} \mathrm{C}\right] \mathrm{AF} 150(\mathrm{~S})$ as a potential M1ACh-R agonist PET ligand.

Recently, [ $\left.{ }^{11} \mathrm{C}\right] \mathrm{AF} 150(\mathrm{~S})$ has been synthesised successfully. Its binding properties and specificity for M1ACh-R were evaluated by in vitro autoradiography; high uptake in rat brain, possibly by facilitated transport mechanisms, was demonstrated in studies ex vivo [31].

In the present study, brain uptake and binding of $\left[{ }^{11} \mathrm{C}\right]$ AF150(S) were studied in rats using PET in order to explore its suitability as an agonist PET ligand for M1ACh-R. In vivo specificity of binding and sensitivity to changes in extracellular levels of ACh were examined by treatment with various pharmacological agents.

\section{Methods}

\section{Materials}

Xanomeline was obtained from Metina AB (Lund, Sweden); pirenzepine, trihexyphenidyl and haloperidol were purchased from Sigma-Aldrich (Zwijndrecht, The Netherlands); darifenacin was obtained from Sequoia Research Products Ltd. (Pangbourne, UK). AF-DX 384 was purchased from Tocris Bioscience (Bristol, UK), and rivastigmine was purchased from AvaChem Scientific 
LLC (San Antonio, TX, USA). Both AF400, the precursor for radiolabelling, and reference AF150(S) were provided by the Israel Institute for Biological Research, Ness-Ziona, Israel.

Compounds were dissolved in saline for in vivo application, except for xanomeline and haloperidol which were dissolved in ethanol and further diluted with saline (final concentration of ethanol, <10\%). AF-DX 384 was dissolved in dimethyl sulfoxide (DMSO) and diluted with saline (final concentration of DMSO, <5\%).

Cold (non-radiolabelled) AF150(S) was dissolved in saline to obtain a $10-\mathrm{mmol} \mathrm{L}^{-1}$ stock solution, from which further dilutions were made. Concentrations of AF150(S) in all solutions were verified by HPLC.

\section{Animals}

Experiments were performed with male Wistar rats (304 \pm 43 g; Harlan Netherlands B.V. Horst, The Netherlands). The rats were kept in conditioned housing under a regular light/dark cycle $(12 / 12 \mathrm{~h})$ and allowed food and water ad libitum. All animal experiments were in compliance with Dutch law and approved by the VU University Animal Ethics Committee.

\section{Radiochemistry}

$\left[{ }^{11} \mathrm{C}\right] \mathrm{AF} 150(\mathrm{~S})$ was synthesised as previously described by methylation of the desmethyl precursor (AF400) using $\left[{ }^{11} \mathrm{C}\right]$ methyl iodide [31]. The final product had a radiochemical purity $>99 \%$ and a specific activity (SA) of 23 to $118 \mathrm{GBq} \mu \mathrm{mol}^{-1}$ at the end of synthesis. $\left[{ }^{18} \mathrm{~F}\right] \mathrm{NaF}$ was prepared as described previously [32]. Both radiotracers were formulated in an isotonic, sterile and pyrogen-free solution for intravenous (IV) injection.

\section{PET studies}

PET scanner

PET measurements were performed using an ECAT high-resolution research tomograph (HRRT) (CTI/Siemens, Knoxville, TN, USA). The ECAT HRRT is a dedicated human brain PET scanner, with design features that enable high spatial resolution combined with high sensitivity, making it also suitable for small-animal imaging. This scanner has a field of view of 312 and 250 $\mathrm{mm}$ in transaxial and axial directions, respectively. The spatial resolution ranges from 2.3 to $3.2 \mathrm{~mm}$ full width at half maximum (FWHM) in the transaxial direction and from 2.5 to $3.4 \mathrm{~mm}$ FWHM in the axial direction, depending on the distance from the centre as described previously [33].

\section{Scan protocol}

Anaesthesia was induced and maintained by constant insufflation of $1.5 \%$ to $2 \%$ isoflurane in pure oxygen. Animals were placed in a fixation device with a tooth bar to secure a fixed and immobile horizontal position of the head during scanning. Body temperature was kept constant at $37^{\circ} \mathrm{C}$ with a heating pad coupled to a thermostat, which was connected to a rectal thermometer. A cannula was inserted into the vena femoralis for radiotracer injection. Transmission measurements of 6-min duration were performed using a $740-\mathrm{MBq} 2 \mathrm{D}$ fan-collimated ${ }^{137} \mathrm{Cs}$ moving point source.

An IV bolus of $15.5 \pm 4.2 \mathrm{MBq}$ of $\left[{ }^{11} \mathrm{C}\right] \mathrm{AF} 150(\mathrm{~S})$ was injected. At the first injection for baseline scanning, the $\mathrm{SA}$ was $71 \pm 16 \mathrm{GBq} \mu \mathrm{mol}^{-1}$; at the second injection, following pre-treatment, SA was $9 \pm 2 \mathrm{GBq} \mu \mathrm{mol}^{-1}$. A three-dimensional (3D) emission scan was acquired, starting immediately prior to the IV injection and lasting for $45 \mathrm{~min}$. At the end of the $\left[{ }^{11} \mathrm{C}\right] \mathrm{AF} 150(\mathrm{~S})$ scans, $\left[{ }^{18} \mathrm{~F}\right]$ $\mathrm{NaF}(15.2 \pm 4.5 \mathrm{MBq})$ was injected, and 30 min later, an emission scan was acquired for $30 \mathrm{~min}$.

\section{Image reconstruction}

Acquired PET data were stored in 64-bit list mode format and, for $\left[{ }^{11} \mathrm{C}\right] \mathrm{AF} 150(\mathrm{~S})$, were subsequently histogrammed into 21 frames with progressive duration $(7 \times 10,1 \times 20$, $2 \times 30,2 \times 60,2 \times 150$ and $7 \times 300 \mathrm{~s})$. The $\left[{ }^{18} \mathrm{~F}\right] \mathrm{NaF}$ data were histogrammed into a single frame of $30 \mathrm{~min}$. Data were reconstructed using 3D ordered subsets weighted least squares [34] using seven iterations and 16 subsets. All data were normalised and corrected for attenuation, randoms, scatter, decay and dead time. All images were reconstructed into a matrix of $256 \times 256 \times 207$ voxels with a voxel size of $1.218 \times 1.218 \times 1.218 \mathrm{~mm}^{3}$.

\section{Pre-treatment with muscarinic agents}

A total of 20 rats were used to examine the binding specificity of $\left[{ }^{11} \mathrm{C}\right] \mathrm{AF} 150(\mathrm{~S})$ in the brain. Rats were randomised into five groups of four rats, and for each rat, two consecutive $\left[{ }^{11} \mathrm{C}\right] \mathrm{AF} 150(\mathrm{~S})$ scans were acquired with a 30-min interval. The first scan was performed under baseline conditions, providing information on regional distribution and kinetics of $\left[{ }^{11} \mathrm{C}\right] \mathrm{AF} 150(\mathrm{~S})$ in the brain. The second scan was performed following pre-treatment with either the M4/M1ACh-R agonist xanomeline (5 or $30 \mathrm{mg} \mathrm{kg}^{-1}$ subcutaneous (SC)) [35], the M1ACh-R antagonists pirenzepine (30 $\mathrm{mg} \mathrm{kg}^{-1} \mathrm{SC}$ ) [36] or trihexyphenidyl (3 $\mathrm{mg} \mathrm{kg}^{-1} \mathrm{SC}$ ) [37], or the M3ACh-R antagonist darifenacin (3 $\mathrm{mg} \mathrm{kg}^{-1}$ IV) [38]. Xanomeline, pirenzepine and trihexyphenidyl were administered $30 \mathrm{~min}$ and darifenacin $15 \mathrm{~min}$ prior to $\left[{ }^{11} \mathrm{C}\right]$ AF150(S) injection.

\section{Pre-treatment with agents affecting extracellular ACh levels}

Twelve rats were used to examine indirect effects of haloperidol (a dopamine $\mathrm{D}_{2}$ antagonist and $\sigma$ site ligand) [39] and AF-DX 384 (an M2/M4ACh-R antagonist) [40], the latter with and without the acetylcholine esterase 
(AChE) inhibitor rivastigmine [41], on $\left[{ }^{11} \mathrm{C}\right] \mathrm{AF} 150(\mathrm{~S})$ binding. Rats were randomised into three groups of four rats. In each animal, two consecutive scans were performed with a 45-min interval. The first scan was performed under baseline conditions, and the second after pre-treatment with haloperidol $\left(1 \mathrm{mg} \mathrm{kg}^{-1} \mathrm{SC}\right)$, the combination of AF-DX $384\left(5 \mathrm{mg} \mathrm{kg}^{-1}\right.$ intraperitoneal (IP)) and rivastigmine (2.5 $\mathrm{mg} \mathrm{kg}^{-1} \mathrm{SC}$ ), or AF-DX 384 (5 $\mathrm{mg} \mathrm{kg}^{-1} \mathrm{IP}$ ). Haloperidol and AF-DX 384 were administered $30 \mathrm{~min}$ and rivastigmine $45 \mathrm{~min}$ prior to the $\left[{ }^{11} \mathrm{C}\right] \mathrm{AF} 150(\mathrm{~S})$ injection.

\section{Co-injection of $\left[{ }^{11} \mathrm{C}\right] A F 150(S)$ with cold AF150(S)}

Twelve rats were used to investigate the effect of coinjection of cold AF150(S) on the total amount of AF150 (S) taken up into the brain. Cold AF150(S) (1, 5 and 15 nmol, respectively) was added to the dose of $\left[{ }^{11} \mathrm{C}\right] \mathrm{AF} 150$ $(\mathrm{S})$ in the syringe, right before intravenous injection. Rats were randomised into three groups of four animals; each animal underwent two consecutive scans with a 30-min interval. First, each rat received an injection of undiluted $\left[{ }^{11} \mathrm{C}\right] \mathrm{AF} 150$ (S) to register a baseline scan; before the second scan, rats received an injection of $\left[{ }^{11} \mathrm{C}\right]$ AF150(S) diluted with cold AF150(S).

\section{Data analysis}

\section{Region of interest analysis}

$\left[{ }^{18} \mathrm{~F}\right] \mathrm{NaF}$ scans were co-registered with a standard magnetic resonance $(\mathrm{MR})$ rat brain template to delineate regions of interest (ROIs); this method was previously described and validated with $\left[{ }^{11} \mathrm{C}\right] \mathrm{AF} 150(\mathrm{~S})$ in rats [42]. The following ROIs were used: left striatum $\left(15 \mathrm{~mm}^{3}\right)$, right striatum $\left(15 \mathrm{~mm}^{3}\right)$, hippocampus (left and right together, $27 \mathrm{~mm}^{3}$ ), frontal plus parietal cortical area (49 $\mathrm{mm}^{3}$ ), posterior plus occipital cortical area $\left(49 \mathrm{~mm}^{3}\right)$ and cerebellum $\left(86 \mathrm{~mm}^{3}\right)$. ROIs were transferred onto dynamic PET images in order to calculate regional radioactivity concentrations $\left(\mathrm{kBq} \mathrm{mL} L^{-1}\right)$ and to generate regional time-activity curves (TACs). TACs were also normalised for generation of standardised uptake values (SUVs) [43].

\section{Binding potential}

The simplified reference tissue model (SRTM) [44], with cerebellum as reference tissue, was used to calculate non-displaceable binding potential $\left(\mathrm{BP}_{\mathrm{ND}}\right)$ as an outcome measure of specific binding.

\section{Statistical analysis}

Differences in regional $\mathrm{BP}_{\mathrm{ND}}$ values at baseline were assessed using one-way ANOVA with Bonferroni correction, and differences in $\mathrm{BP}_{\mathrm{ND}}$ values before and after treatment with various agents or co-administration of non-radioactive AF150(S) were tested using a general
Linear Mixed Model (SPSS Statistics version 17.0; SPSS Inc., Chicago, IL, USA). All results are expressed as mean \pm standard deviation (SD), and values of $p<0.05$ were considered to be statistically significant.

\section{Results}

\section{Baseline uptake}

$\left[{ }^{11} \mathrm{C}\right] \mathrm{AF} 150(\mathrm{~S})$ uptake in brain regions under baseline conditions was examined in a total of 44 rats. Average timeactivity curves for five brain regions are shown in Figure 1A. Following intravenous injection of $\left[{ }^{11} \mathrm{C}\right] \mathrm{AF} 150(\mathrm{~S})$, radioactivity in all brain regions rapidly increased and reached its maximum within the first minute after injection. Uptake in the striatum, hippocampus and the two cortical areas was higher than in the cerebellum. Clearance of radioactivity from the brain was relatively fast, especially in the cerebellum. The maximum brain concentration measured was, on average, $155 \pm 26 \mathrm{kBq}$ $\mathrm{mL}^{-1}$ corresponding to $2.9 \pm 0.5 \mathrm{nM}\left[{ }^{11} \mathrm{C}\right] \mathrm{AF} 150(\mathrm{~S})$.

SUV ratios (SUVr) of the brain region over the cerebellum as a function of time are shown in Figure 1B. SUVr values were maximal at $5.8 \mathrm{~min}$, ranging from $1.19 \pm 0.07$ for the posterior cortical area to $1.35 \pm 0.05$ for the striatum.

$\left[{ }^{11} \mathrm{C}\right] \mathrm{AF} 150(\mathrm{~S})$ specific binding in M1ACh-R-rich brain areas was determined using SRTM with the cerebellum as reference tissue. $\mathrm{BP}_{\mathrm{ND}}$ values are presented in Table 1 . $\mathrm{BP}_{\mathrm{ND}}$ under baseline conditions ranged from 0.25 to 0.15 , with a regional rank order of striatum $>$ hippocampus $>$ frontal cortical area $\approx$ posterior cortical area. Findings were quite consistent across the five groups of four rats. Representative images of baseline $\left[{ }^{11} \mathrm{C}\right] \mathrm{AF} 150(\mathrm{~S})$ uptake and corresponding parametric $\mathrm{BP}_{\mathrm{ND}}$ are shown in Figure 2.

\section{Pre-treatment with muscarinic agents}

In Table 1, the $\mathrm{BP}_{\mathrm{ND}}$ values in five brain regions following pre-treatment with xanomeline, pirenzepine, trihexyphenidyl and darifenacin are shown. Following pretreatment with xanomeline at $5 \mathrm{mg} \mathrm{kg}^{-1},\left[{ }^{11} \mathrm{C}\right] \mathrm{AF} 150(\mathrm{~S})$ $\mathrm{BP}_{\mathrm{ND}}$ significantly increased by $20 \%$ and $19 \%$ in the left striatum and hippocampus, respectively. Xanomeline at a higher dose $\left(30 \mathrm{mg} \mathrm{kg}^{-1}\right)$ did not result in significant changes in $\mathrm{BP}_{\mathrm{ND}}$ in any of the brain areas investigated. This high dose caused severe side effects, such as strongly increased heart rate, salivation and irregular breathing. Pre-treatment with pirenzepine and trihexyphenidyl caused significant reductions in $\mathrm{BP}_{\mathrm{ND}}$. With pirenzepine, reductions of $37 \%, 32 \%$ and $16 \%$ were seen in the frontal cortical area, posterior cortical area and left striatum, respectively. Trihexyphenidyl caused reductions in the frontal cortical area, posterior cortical area and hippocampus of $53 \%, 56 \%$ and $13 \%$, respectively. Pre-treatment with 


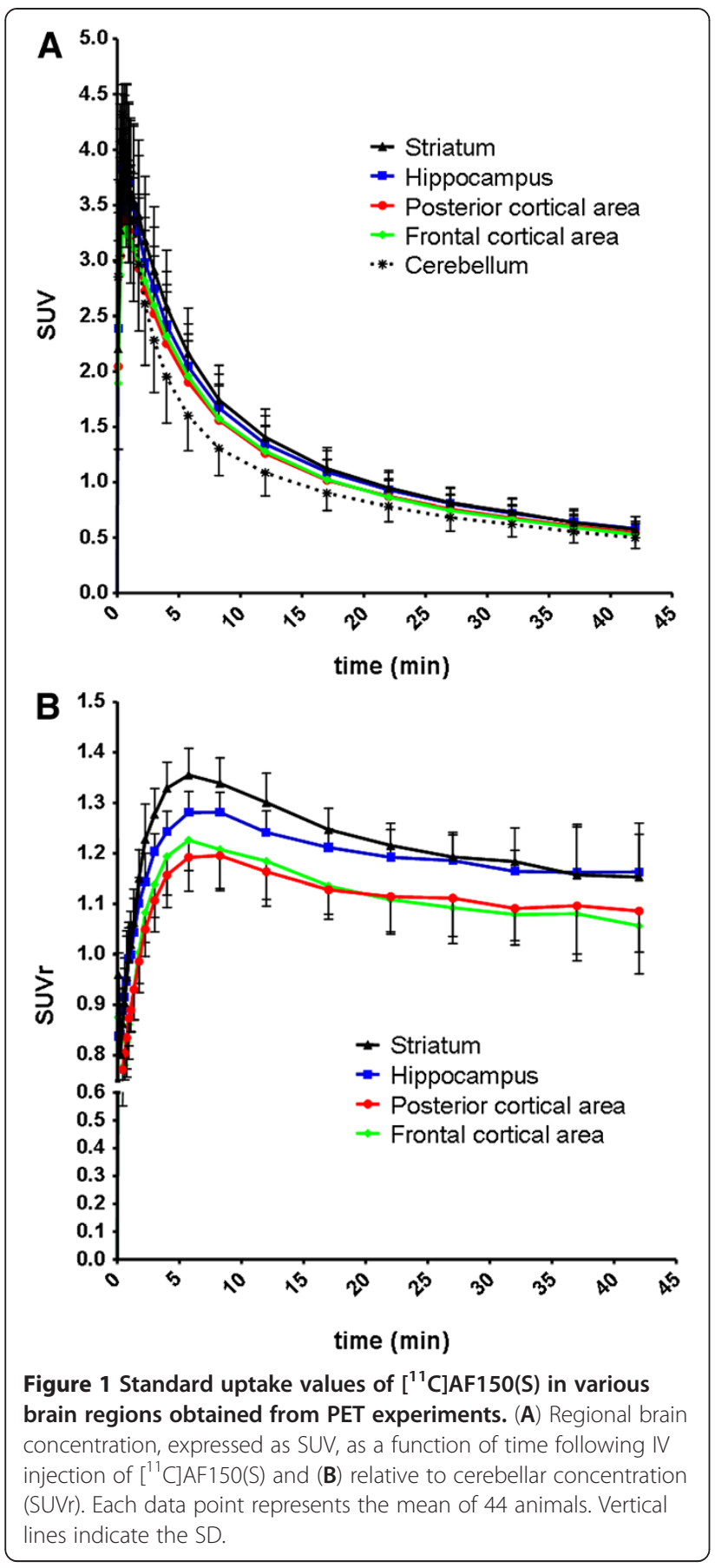

darifenacin had no measurable effect on $\left[{ }^{11} \mathrm{C}\right] \mathrm{AF} 150(\mathrm{~S})$ binding in any brain region.

\section{Pre-treatment with agents affecting extracellular ACh levels}

Table 2 provides $\mathrm{BP}_{\mathrm{ND}}$ values in five brain areas following pre-treatment with haloperidol, AF-DX 384 and AFDX 384 plus rivastigmine. Haloperidol pre-treatment resulted in significant reductions in $\mathrm{BP}_{\mathrm{ND}}$ in the right striatum and hippocampus of $27 \%$ and $15 \%$, respectively.
The animals showed severe rigidity following the haloperidol treatment. Pre-treatment with AF-DX 384, however, did not show any significant changes in $\mathrm{BP}_{\mathrm{ND}}$. The addition of rivastigmine to AF-DX 384 pre-treatment resulted in significant increases in $\mathrm{BP}_{\mathrm{ND}}$ of $\left[{ }^{11} \mathrm{C}\right] \mathrm{AF} 150$ (S) in the right striatum, hippocampus and frontal cortical area of $22 \%, 12 \%$ and $24 \%$, respectively. These treatments did not have an apparent effect on the animal's behaviour or body posture.

\section{Co-injection with cold AF150(S)}

In Table 3, doses of co-injected cold AF150(S) and resulting SA of injected $\left[{ }^{11} \mathrm{C}\right] \mathrm{AF} 150(\mathrm{~S})$ are shown. The aim of the experiment was to explore whether an AF150 (S) concentration occupancy curve could be achieved. Effects of co-injection of cold AF150(S) on the regional brain uptake of total AF150(S) (radioactive + cold calculated according to the SA of the injected sample), measured at $5.8 \mathrm{~min}$ after injection, are shown in Figure 3. The increase in brain concentration of total AF150(S) was larger when based on a linear relationship between injected dose and brain concentration. Possible metabolism of AF150(S) was not taken into account. Calculated $\mathrm{BP}_{\mathrm{ND}}$ values under baseline conditions and after coadministration of cold AF150(S) were not significantly different, see Table 4 . Hence, a saturation curve of specific binding of AF150(S) could not be constructed.

\section{Discussion}

$\left[{ }^{11} \mathrm{C}\right] \mathrm{AF} 150(\mathrm{~S})$ brain uptake under baseline conditions

Under baseline conditions, brain kinetics of $\left[{ }^{11} \mathrm{C}\right] \mathrm{AF} 150$ (S) were very rapid with peak values being reached within $1 \mathrm{~min}$ after injection, followed by a rapid decline. The calculated maximal brain concentration of $\left[{ }^{11} \mathrm{C}\right]$ AF150(S) of $2.9 \mathrm{nM}$ remained approximately 70 times below the $K_{\mathrm{d}, \mathrm{H}}(200 \mathrm{nM})$, of AF150(S) for M1ACh-R, under baseline conditions. In consecutive scans (baseline and following pre-treatment), the same synthesis batch of $\left[{ }^{11} \mathrm{C}\right] \mathrm{AF} 150(\mathrm{~S})$ was used. As a consequence, the SA was about eight times lower at the second injection, and to keep the injected amount of radioactivity constant, a larger dose of AF150(S) was injected.

SUVr data showed increased retention in M1ACh-Rrich areas. The rank order of uptake, striatum $\geq$ hippocampus $>$ frontal cortical area $>$ posterior cortical area $>>$ cerebellum, corresponds with the rank order of M1ACh-R density measured in vitro in rat brain [4]. These findings also confirm previous biodistribution data with $\left[{ }^{11} \mathrm{C}\right] \mathrm{AF} 150(\mathrm{~S})$ uptake measured ex vivo [31]. Note that the parametric image under baseline conditions clearly shows $\left[{ }^{11} \mathrm{C}\right] \mathrm{AF} 150(\mathrm{~S})$ uptake in the hippocampus (Figure 2). $\mathrm{BP}_{\mathrm{ND}}$ values could successfully be derived by applying SRTM referring to the cerebellum, a region which is essentially devoid of M1ACh-R [4]. This 
Table $1 \mathrm{BP}_{\mathrm{ND}}$ of $\left[{ }^{11} \mathrm{C}\right] \mathrm{AF} 150$ (S) before and after treatment with various muscarinic agents

\begin{tabular}{|c|c|c|c|c|c|c|c|c|c|c|c|}
\hline \multirow[t]{2}{*}{ Brain region } & \multicolumn{2}{|c|}{$\begin{array}{c}\text { Xanomeline } \\
\left.\text { (5 } \mathrm{mg} \mathrm{kg}^{-1} \mathrm{sC}\right)\end{array}$} & \multicolumn{2}{|c|}{$\begin{array}{c}\text { Xanomeline } \\
\left.\text { (30 } \mathrm{mg} \mathrm{kg}^{-1} \mathrm{SC}\right)\end{array}$} & \multicolumn{2}{|c|}{$\begin{array}{c}\text { Pirenzepine } \\
\left(30 \mathrm{mg} \mathrm{kg}^{-1} \mathrm{SC}\right)\end{array}$} & \multicolumn{2}{|c|}{$\begin{array}{l}\text { Trihexyphenidyl } \\
\left.\text { (3 mg kg }{ }^{-1} \mathrm{SC}\right)\end{array}$} & \multicolumn{2}{|c|}{$\begin{array}{c}\text { Darifenacin } \\
\left(3 \mathrm{mg} \mathrm{kg}^{-1} \mathrm{IV}\right)\end{array}$} & \multirow{2}{*}{$\begin{array}{c}\text { Mean } \\
(n=20) \\
\text { Baseline }\end{array}$} \\
\hline & Baseline & $\begin{array}{c}\text { Pre- } \\
\text { treated }\end{array}$ & Baseline & $\begin{array}{l}\text { Pre- } \\
\text { treated }\end{array}$ & Baseline & $\begin{array}{c}\text { Pre- } \\
\text { treated }\end{array}$ & Baseline & $\begin{array}{c}\text { Pre- } \\
\text { treated }\end{array}$ & Baseline & $\begin{array}{l}\text { Pre- } \\
\text { treated }\end{array}$ & \\
\hline Left striatum & $\begin{array}{l}0.25 \pm \\
0.05\end{array}$ & $\begin{array}{l}0.30 \pm \\
0.04^{*}\end{array}$ & $\begin{array}{c}0.22 \pm \\
0.07\end{array}$ & $\begin{array}{l}0.22 \pm \\
0.05\end{array}$ & $\begin{array}{c}0.25 \pm \\
0.04\end{array}$ & $\begin{array}{l}0.21 \pm \\
0.05^{*}\end{array}$ & $\begin{array}{l}0.24 \pm \\
0.02\end{array}$ & $\begin{array}{c}0.21 \pm \\
0.01\end{array}$ & $\begin{array}{l}0.29 \pm \\
0.03\end{array}$ & $\begin{array}{c}0.28 \pm \\
0.04\end{array}$ & $\begin{array}{l}0.25 \pm \\
0.05^{\mathrm{a}}\end{array}$ \\
\hline Right striatum & $\begin{array}{l}0.24 \pm \\
0.04\end{array}$ & $\begin{array}{c}0.27 \pm \\
0.01\end{array}$ & $\begin{array}{c}0.23 \pm \\
0.08\end{array}$ & $\begin{array}{l}0.25 \pm \\
0.06\end{array}$ & $\begin{array}{l}0.25 \pm \\
0.06\end{array}$ & $\begin{array}{l}0.23 \pm \\
0.03\end{array}$ & $\begin{array}{c}0.22 \pm \\
0.01\end{array}$ & $\begin{array}{c}0.22 \pm \\
0.01\end{array}$ & $\begin{array}{l}0.26 \pm \\
0.05\end{array}$ & $\begin{array}{l}0.26 \pm \\
0.03\end{array}$ & $\begin{array}{l}0.24 \pm \\
0.05^{b}\end{array}$ \\
\hline Hippocampus & $\begin{array}{l}0.20 \pm \\
0.03\end{array}$ & $\begin{array}{c}0.24 \pm \\
0.01^{*}\end{array}$ & $\begin{array}{c}0.19 \pm \\
0.04\end{array}$ & $\begin{array}{c}0.19 \pm \\
0.06\end{array}$ & $\begin{array}{l}0.20 \pm \\
0.03\end{array}$ & $\begin{array}{l}0.18 \pm \\
0.02\end{array}$ & $\begin{array}{c}0.19 \pm \\
0.01\end{array}$ & $\begin{array}{l}0.16 \pm \\
0.01^{* *}\end{array}$ & $\begin{array}{l}0.24 \pm \\
0.02\end{array}$ & $\begin{array}{l}0.22 \pm \\
0.04\end{array}$ & $\begin{array}{l}0.20 \pm \\
0.03^{c}\end{array}$ \\
\hline $\begin{array}{l}\text { Frontal cortical } \\
\text { area }\end{array}$ & $\begin{array}{c}0.12 \pm \\
0.07\end{array}$ & $\begin{array}{c}0.10 \pm \\
0.04\end{array}$ & $\begin{array}{c}0.17 \pm \\
0.06\end{array}$ & $\begin{array}{l}0.14 \pm \\
0.04\end{array}$ & $\begin{array}{l}0.16 \pm \\
0.05\end{array}$ & $0.10 \pm$ & $\begin{array}{l}0.11 \pm \\
0.03\end{array}$ & $\begin{array}{l}0.05 \pm \\
0.03^{*}\end{array}$ & $\begin{array}{l}0.22 \pm \\
0.02\end{array}$ & $\begin{array}{l}0.20 \pm \\
0.06\end{array}$ & $\begin{array}{l}0.16 \pm \\
0.06^{d}\end{array}$ \\
\hline $\begin{array}{l}\text { Posterior cortical } \\
\text { area }\end{array}$ & $\begin{array}{c}0.12 \pm \\
0.06\end{array}$ & $\begin{array}{c}0.10 \pm \\
0.04\end{array}$ & $\begin{array}{l}0.15 \pm \\
0.06\end{array}$ & $\begin{array}{l}0.13 \pm \\
0.04\end{array}$ & $\begin{array}{l}0.13 \pm \\
0.03\end{array}$ & $\begin{array}{l}0.09 \pm \\
0.03^{* *}\end{array}$ & $\begin{array}{l}0.11 \pm \\
0.05\end{array}$ & $\begin{array}{l}0.05 \pm \\
0.03^{*}\end{array}$ & $\begin{array}{c}0.23 \pm \\
0.01\end{array}$ & $\begin{array}{l}0.18 \pm \\
0.05\end{array}$ & $\begin{array}{l}0.15 \pm \\
0.06^{\mathrm{e}}\end{array}$ \\
\hline
\end{tabular}

Data are presented as mean \pm SD ( $n=4$ per group). IV, intravenous; SC, subcutaneous. Significant difference compared with baseline: ${ }^{*} p<0.05,{ }^{* *} p<0.01$.

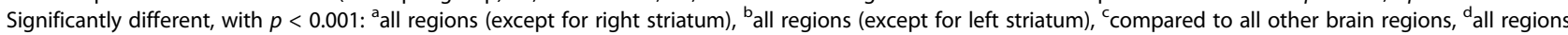
(except for the posterior cortical area), or eall regions (except for the frontal cortical area).

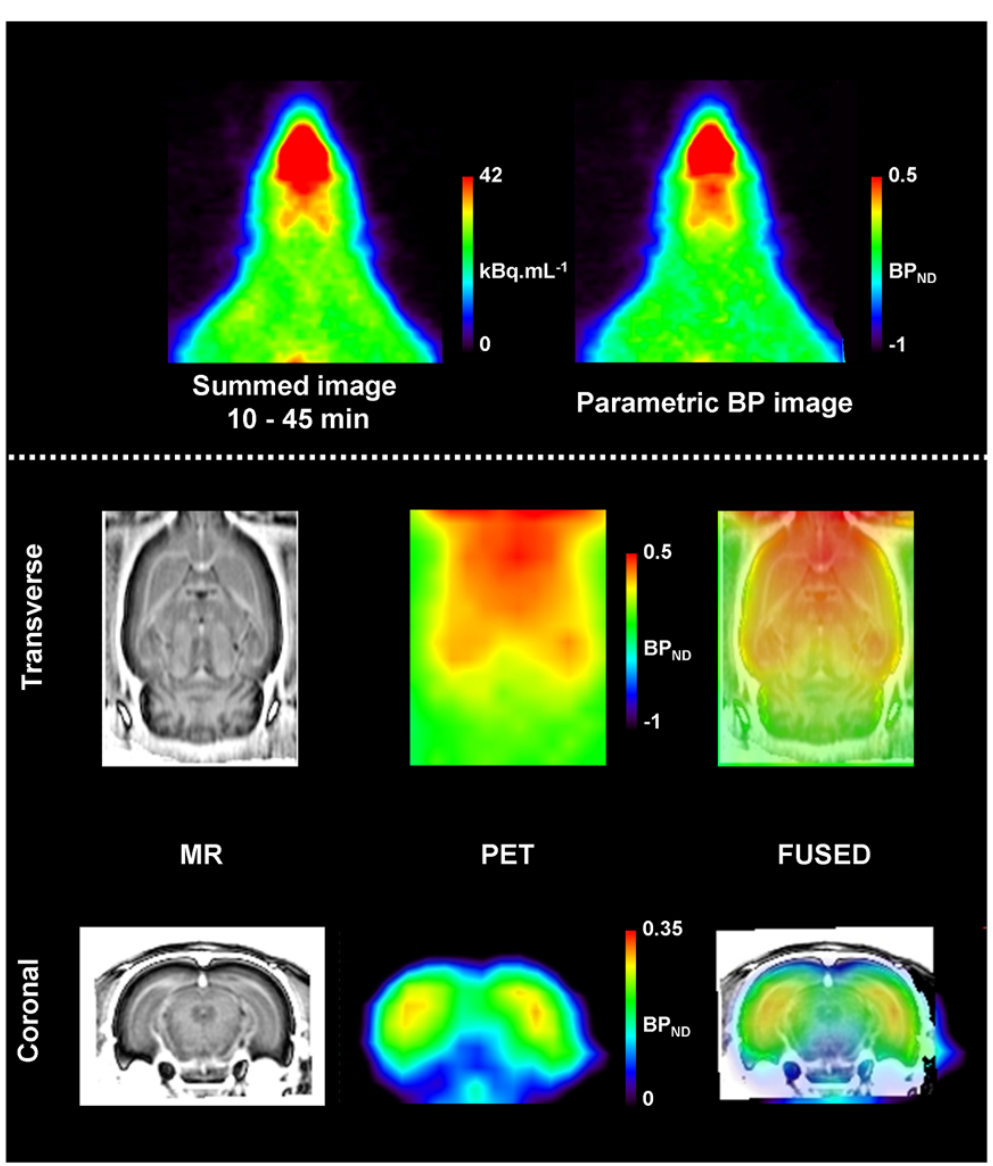

Figure 2 Example of a $\left[{ }^{11} \mathrm{C}\right] \mathrm{AF} 150$ (S) PET image of the brain. Summed (10 to $45 \mathrm{~min}$ after injection) baseline $\left[{ }^{11} \mathrm{C}\right] \mathrm{AF} 150(\mathrm{~S})$ uptake image together with corresponding parametric non-displaceable binding potential (BP $\mathrm{ND}$ ) image. Corresponding MR slices and fused images are shown for anatomical reference. 
Table $2 \mathrm{BP}_{\mathrm{ND}}$ of $\left[{ }^{11} \mathrm{C}\right] \mathrm{AF} 150(\mathrm{~S})$ without and with pre-treatment with agents that increase extracellular levels of ACh

\begin{tabular}{|c|c|c|c|c|c|c|}
\hline \multirow[t]{2}{*}{ Brain region } & \multicolumn{2}{|c|}{$\begin{array}{c}\text { Haloperidol } \\
\left(1 \mathrm{mg} \mathrm{kg}^{-1} \mathrm{SC}\right)\end{array}$} & \multicolumn{2}{|c|}{$\begin{array}{c}\text { AF-DX } 384 \\
\left(5 \mathrm{mg} \mathrm{kg}^{-1} \mathrm{IP}\right)\end{array}$} & \multicolumn{2}{|c|}{$\begin{array}{c}\text { AF-DX } 384 \text { and rivastigmine } \\
\left(5 \mathrm{mg} \mathrm{kg}^{-1} \mathrm{IP} \text { and } 2.5 \mathrm{mg} \mathrm{kg}^{-1} \mathrm{SC}\right)\end{array}$} \\
\hline & Baseline & Pre-treated & Baseline & Pre-treated & Baseline & Pre-treated \\
\hline Left striatum & $0.23 \pm 0.04$ & $0.18 \pm 0.01$ & $0.27 \pm 0.06$ & $0.32 \pm 0.04$ & $0.25 \pm 0.05$ & $0.27 \pm 0.03$ \\
\hline Right striatum & $0.28 \pm 0.05$ & $0.21 \pm 0.03^{*}$ & $0.30 \pm 0.04$ & $0.33 \pm 0.05$ & $0.23 \pm 0.05$ & $0.29 \pm 0.03^{*}$ \\
\hline Hippocampus & $0.19 \pm 0.02$ & $0.16 \pm 0.01^{*}$ & $0.26 \pm 0.04$ & $0.26 \pm 0.02$ & $0.22 \pm 0.02$ & $0.25 \pm 0.01^{*}$ \\
\hline Frontal cortical area & $0.10 \pm 0.06$ & $0.06 \pm 0.04$ & $0.24 \pm 0.02$ & $0.24 \pm 0.06$ & $0.17 \pm 0.03$ & $0.21 \pm 0.02^{* *}$ \\
\hline Posterior cortical area & $0.07 \pm 0.07$ & $0.06 \pm 0.04$ & $0.21 \pm 0.03$ & $0.22 \pm 0.05$ & $0.19 \pm 0.04$ & $0.19 \pm 0.04$ \\
\hline
\end{tabular}

Data are presented as mean \pm SD ( $n=4$ per group). SC, subcutaneous; IP, intraperitoneal. Significant difference compared with baseline: ${ }^{*} p<0.05,{ }^{* *} p<0.01$.

particular reference model best fitted the $\left[{ }^{11} \mathrm{C}\right] \mathrm{AF} 150(\mathrm{~S})$ PET data. Furthermore, a reference tissue model was chosen for data analysis as no arterial input function could readily be obtained from rats.

\section{Pre-treatment with muscarinic agents}

Pre-treatment conditions, i.e. time of injection and dose of the applied compounds, were chosen according to their maximal pharmacological activity in rats. Pre-treatment with the M1ACh-R selective antagonists pirenzepine and trihexyphenidyl caused a decrease in $\mathrm{BP}_{\mathrm{ND}}$ of $\left[{ }^{11} \mathrm{C}\right] \mathrm{AF} 150$ (S) in the frontal and posterior cortical areas. In addition, pirenzepine caused a significant reduction in $\mathrm{BP}_{\mathrm{ND}}$ in the left striatum, and trihexyphenidyl in the hippocampus, indicative of a reduction in specific binding to M1ACh-R in these regions.

The M4/M1ACh-R agonist xanomeline, selected to investigate agonist-agonist competition, at a dose of $5 \mathrm{mg}$ $\mathrm{kg}^{-1}$ caused an increase in $\mathrm{BP}_{\mathrm{ND}}$ in the striatum and hippocampus, whereas a decrease would have been expected if $\left[{ }^{11} \mathrm{C}\right] \mathrm{AF} 150(\mathrm{~S})$ and xanomeline are competing for the same binding site. Since GPCRs are dynamic structures that undergo configurational changes upon agonist binding, several explanations are possible for this apparent anomalous finding. Xanomeline is reported to induce M1ACh-R activation via both orthosteric and ectopic binding sites $[45,46]$. Xanomeline-induced activation of the ectopic site could cause increased M1ACh-R G protein coupling by which more activated orthosteric sites become available for $\left[{ }^{11} \mathrm{C}\right] \mathrm{AF} 150(\mathrm{~S})$ binding, leading to higher $\mathrm{BP}_{\mathrm{ND}}$ of $\left[{ }^{11} \mathrm{C}\right] \mathrm{AF} 150(\mathrm{~S})$. An alternative explanation could be the effect of xanomeline on M4ACh-R. $\mathrm{M} 4 \mathrm{ACh}-\mathrm{R}$ is an autoreceptor, predominantly present in the striatum and hippocampus [47]. Agonist stimulation of M4ACh-R leads to a decrease in acetylcholine release [48], potentially resulting in reduced competition between endogenous extracellular acetylcholine and $\left[{ }^{11} \mathrm{C}\right] \mathrm{AF} 150(\mathrm{~S})$, which in turn may result in increased binding of $\left[{ }^{11} \mathrm{C}\right] \mathrm{AF} 150(\mathrm{~S})$. However, a higher dose of xanomeline $\left(30 \mathrm{mg} \mathrm{kg}^{-1}\right)$ that caused severe peripheral and cardiac effects, and glandular secretion, did not show any significant effect on $\mathrm{BP}_{\mathrm{ND}}$ of $\left[{ }^{11} \mathrm{C}\right] \mathrm{AF} 150(\mathrm{~S})$ in M1ACh-R-rich areas. Therefore, the observed effects of xanomeline seem to be dose dependent, and pharmacokinetic effects may play a role.

In vitro experiments have demonstrated partial agonist/ antagonist effects of AF150(S) on M3ACh-R (Fisher et al., 2007, unpublished results). M3ACh-R is present in glands and can also be found on smooth muscles of blood vessels and at low density in the brain [49]. Darifenacin, an M3 antagonist with central activity, was selected to check for possible labelling of M3ACh-R by $\left[{ }^{11} \mathrm{C}\right] \mathrm{AF} 150$ (S). Pretreatment with darifenacin, however, did not significantly reduce $\mathrm{BP}_{\mathrm{ND}}$ of $\left[{ }^{11} \mathrm{C}\right] \mathrm{AF} 150(\mathrm{~S})$ in any brain region. Hence, $\left[{ }^{11} \mathrm{C}\right] \mathrm{AF} 150$ (S) appears not to show measurable binding to M3ACh-R in the brain in vivo.

\section{Pre-treatment with agents affecting extracellular ACh levels}

Pre-treatment conditions, i.e. time of injection and dosing, were chosen to give maximal $\mathrm{ACh}$ release at 5.8 min post intravenous injection of $\left[{ }^{11} \mathrm{C}\right] \mathrm{AF} 150(\mathrm{~S})$ in order to have maximal competition. Haloperidol pre-treatment causes blockade of $\mathrm{D}_{2}$ receptors, which in turn leads to reduced inhibition of the cholinergic system, in particular in the striatum and hippocampus. This results in

Table 3 Overview of injected doses of $\left[{ }^{11} \mathrm{C}\right] \mathrm{AF150}$ (S) and AF150(S)

\begin{tabular}{|c|c|c|c|c|}
\hline $\begin{array}{l}\text { Cold AF150(S) co-injected } \\
\text { per rat (nmol) }\end{array}$ & Number & $\begin{array}{l}{\left[{ }^{11} \mathrm{C}\right] \mathrm{AF} 150(\mathrm{~S}) \text { injected }} \\
\text { radioactivity }(\mathrm{MBq})\end{array}$ & $\begin{array}{l}\text { Specific activity of cold diluted }\left[{ }^{11} \mathrm{C}\right] \mathrm{AF} 150(\mathrm{~S}) \text { at } \\
\text { injection }\left(\mathrm{GBq} \mu \mathrm{mol}^{-1}\right)\end{array}$ & $\begin{array}{l}\text { AF150(S) total dose } \\
\left(\mathrm{nmol} \mathrm{kg}^{-1}\right)\end{array}$ \\
\hline 0 & 12 & $16.9 \pm 0.8$ & $82.9 \pm 8.4$ & $0.7 \pm 0.1$ \\
\hline 1 & 4 & $17.8 \pm 0.3$ & $6.4 \pm 0.0$ & $10.9 \pm 0.3$ \\
\hline 5 & 4 & $15.7 \pm 2.1$ & $2.4 \pm 0.3$ & $21.7 \pm 2.2$ \\
\hline 15 & 4 & $18.2 \pm 1.1$ & $1.1 \pm 0.1$ & $49.1 \pm 1.2$ \\
\hline
\end{tabular}




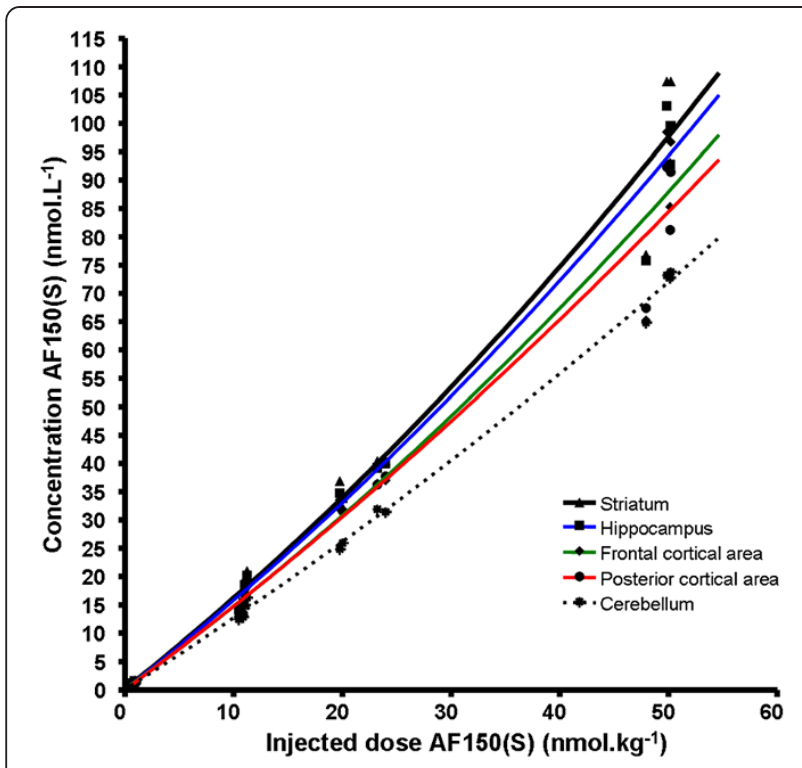

Figure 3 Effect of co-injection of cold AF150(S) on regional brain uptake of $\mathrm{AF} 150$ (S) in various brain regions.

Concentrations of cold AF150(S) in those brain areas were calculated based on measured radioactivity concentrations of $\left[{ }^{11} \mathrm{C}\right] \mathrm{AF} 150(\mathrm{~S})$ at $5.8 \mathrm{~min}$ and the specific activity at the time of injection. Solid lines are the non-linear fits of the data using GraphPad Prism (version 4.00, San Diego, CA, USA). Possible metabolism of AF150(S) was not taken into account.

increased extracellular levels of acetylcholine [50]. Increase in ACh release following haloperidol treatment is demonstrated in in vivo microdialysis studies [51]. Further evidence for increased cholinergic activity is apparent in behavioural studies where haloperidol causes severe catalepsy as a result of cholinergic over-activity in the striatum [52]. Also in this study, at the applied dose, haloperidol caused immobility and severe rigidity in the animals. The significant reductions in $\mathrm{BP}_{\mathrm{ND}}$ of $\left[{ }^{11} \mathrm{C}\right]$ AF150(S) in the right striatum $(-27 \%)$ and hippocampus $(-15 \%)$ following haloperidol treatment can likely be ascribed to increased extracellular ACh levels, which may have competed with $\left[{ }^{11} \mathrm{C}\right] \mathrm{AF} 150(\mathrm{~S})$ for M1ACh-R binding in these particular brain areas.

AF-DX 384 is an M2/M4 selective muscarinic antagonist that acts on M2 autoreceptors located presynaptically on cholinergic nerve terminals. Blockade of the M2 autoreceptor will cause increased release of acetylcholine [53], which could cause competition between ACh and $\left[{ }^{11} \mathrm{C}\right] \mathrm{AF} 150$ (S) for the M1ACh-R, located postsynaptically. In microdialysis studies in rats, AF-DX 384 given IP at a dose of $5 \mathrm{mg} \mathrm{kg}^{-1}$ resulted in a long-lasting significant increase in acetylcholine release, $30 \mathrm{~min}$ after administration, in both the cortex and hippocampus [40]. In those studies, breakdown of extracellular ACh was prevented by adding the $\mathrm{AChE}$ inhibitor physostigmine in the microdialysis perfusate. In the present study, AChE inhibition as protection against $\mathrm{ACh}$ breakdown was attempted by using co-treatment with rivastigmine [41]. AF-DX 384 and rivastigmine, at the present dose, did not cause animal immobility or catalepsy, and such effect on behaviour by AF-DX 384 treatment has neither been reported in the literature. Therefore, the effect-size of M2ACh- $\mathrm{R}$ blockade on acetylcholine release probably is much less pronounced than that of haloperidol. Pre-treatment with only AF-DX 384 also did not have an effect on $\mathrm{BP}_{\mathrm{ND}}$ in M1ACh-R-rich brain areas.

Pre-treatment with AF-DX 384 combined with rivastigmine, surprisingly, resulted in significant increases in $\mathrm{BP}_{\mathrm{ND}}$ of $\left[{ }^{11} \mathrm{C}\right] \mathrm{AF} 150(\mathrm{~S})$ in M1ACh-R-rich brain areas, e.g. the right striatum, hippocampus and frontal cortical area. A tentative explanation for these observed increases in $\mathrm{BP}_{\mathrm{ND}}$ could be agonist-mediated changes in M1ACh-R affinity/availability. This has been proposed for the dopamine $\mathrm{D}_{2}$ receptor radioligand $\left[{ }^{11} \mathrm{C}\right]$ raclopride which demonstrated increased BP after pre-treatment with L-dopa [54]. Unfortunately, experimental evidence to explain such phenomena is hard to obtain. Nevertheless, $\left[{ }^{11} \mathrm{C}\right]$ AF150 binding appears to be sensitive to changes in extracellular ACh levels, in particular when behavioural effects are apparent. Ideally, and in analogy with the dopamine $\mathrm{D}_{2}$ agonist PET ligand studies, the sensitivity of $\left[{ }^{11} \mathrm{C}\right] \mathrm{AF} 150$ (S) to changes in extracellular ACh should be assessed in direct comparison with an M1ACh-R antagonist PET ligand to investigate difference in sensitivity between them. Indeed for the dopamine $\mathrm{D}_{2}$ agonist PET ligands $\left[{ }^{11} \mathrm{C}\right]$ MNPA, $\left[{ }^{11} \mathrm{C}\right] \mathrm{NPA}$ and $\left[{ }^{11} \mathrm{C}\right](+)-\mathrm{PHNO}$, a larger reduction in binding, by increased endogenous dopamine levels following amphetamine pre-treatment, was found as

Table $4 \mathrm{BP}_{\mathrm{ND}}$ of $\left[{ }^{11} \mathrm{C}\right] \mathrm{AF} 150$ (S) without and with co-injection of cold AF150(S)

\begin{tabular}{|c|c|c|c|c|c|c|}
\hline \multirow[t]{2}{*}{ Brain region } & \multicolumn{2}{|c|}{$+1 \mathrm{nmol}$ of cold AF150(S) } & \multicolumn{2}{|c|}{$+5 \mathrm{nmol}$ of cold AF150(S) } & \multicolumn{2}{|c|}{ +15 nmol of cold AF150(S) } \\
\hline & Baseline & Co-injected & Baseline & Co-injected & Baseline & Co-injected \\
\hline Left striatum & $0.23 \pm 0.02$ & $0.21 \pm 0.02$ & $0.26 \pm 0.06$ & $0.25 \pm 0.09$ & $0.28 \pm 0.08$ & $0.31 \pm 0.11$ \\
\hline Right striatum & $0.24 \pm 0.01$ & $0.23 \pm 0.02$ & $0.26 \pm 0.06$ & $0.26 \pm 0.09$ & $0.30 \pm 0.07$ & $0.32 \pm 0.11$ \\
\hline Hippocampus & $0.20 \pm 0.01$ & $0.18 \pm 0.03$ & $0.23 \pm 0.04$ & $0.23 \pm 0.07$ & $0.24 \pm 0.04$ & $0.26 \pm 0.08$ \\
\hline Frontal cortical area & $0.11 \pm 0.04$ & $0.08 \pm 0.03$ & $0.16 \pm 0.06$ & $0.14 \pm 0.09$ & $0.17 \pm 0.09$ & $0.18 \pm 0.12$ \\
\hline Posterior cortical area & $0.08 \pm 0.05$ & $0.06 \pm 0.04$ & $0.16 \pm 0.05$ & $0.13 \pm 0.07$ & $0.14 \pm 0.07$ & $0.13 \pm 0.09$ \\
\hline
\end{tabular}

Statistical analysis: significant difference between baseline and co-injected, $p \geq 0.12$. 
compared to the antagonist PET ligand $\left[{ }^{11} \mathrm{C}\right]$ raclopride [18,55-58]. This can be taken as an indication that the agonist PET ligands preferentially label the $G$ proteincoupled receptors that are the target of the endogenous neurotransmitter. The present observations warrant further studies, preferentially in larger animals, to investigate and further characterise the sensitivity of specific $\left[{ }^{11} \mathrm{C}\right]$ AF150(S) binding in brain regions to alterations in extracellular ACh levels.

\section{Co-injection of $\left[{ }^{11} \mathrm{C}\right] \mathrm{AF} 150(\mathrm{~S})$ with cold AF150(S)}

Increasing amounts of co-injected cold AF150(S) resulted in a more-than linear increase in corresponding brain concentrations of total AF150(S) in M1ACh-R-rich brain areas (Figure 3), whereas in M1ACh-R-poor brain areas, such as the cerebellum, this effect was less pronounced. After coadministration of the highest dose of cold $\mathrm{AF} 150(\mathrm{~S}), \mathrm{BP}_{\mathrm{ND}}$ values were slightly increased compared to baseline conditions, yet due to variability, these values were statistically not significantly different (Table 4). The more-than-linear increase in brain concentrations of $\left[{ }^{11} \mathrm{C}\right] \mathrm{AF} 150(\mathrm{~S})$ in M1ACh-R-rich brain areas is probably not due to diffusion but is a result of facilitated transport of AF150(S) in the brain that was hypothesised from analyses of results in our previous study of $\left[{ }^{11} \mathrm{C}\right] \mathrm{AF} 150$ (S) uptake into the brain ex vivo [31]. The hypothesis was mainly based on (1) the measured low lipophilicity of $\left[{ }^{11} \mathrm{C}\right] \mathrm{AF} 150(\mathrm{~S}), \log \mathrm{D}_{\mathrm{pH}} 7.4=$ 0.05 , which hampers diffusion through lipid cell membranes, (2) the eight-times-higher brain level as compared to plasma levels of $\left[{ }^{11} \mathrm{C}\right] \mathrm{AF} 150(\mathrm{~S})$ and (3) the structural similarity between AF150(S) and nicotine, for which facilitated transport into the brain has been demonstrated.

The highest administered molar dose of nonradiolabelled AF150(S) (approximately $50 \mathrm{nmol} \mathrm{kg}{ }^{-1}$ ) resulted in a brain concentration of approximately 100 nM AF150(S) in vivo, a value that still lies 50\% under the in vitro $K_{\mathrm{d}, \mathrm{H}}$ of $\mathrm{AF} 150(\mathrm{~S})(200 \mathrm{nM})$. At the highest applied dose, no sign of saturation in binding to M1ACh- $R$ was observed; indeed, the latter is only expected to occur at a concentration of $4 \times K_{\mathrm{d}, \mathrm{H}}$. Therefore, saturation should be investigated using a substantial higher dose of non-radiolabelled AF150(S).

\section{Further evaluation of $\left[{ }^{11} \mathrm{C}\right] \mathrm{AF} 150(\mathrm{~S})$ as a potential agonist PET ligand for M1ACh-R}

The findings in this preliminary PET study with $\left[{ }^{11} \mathrm{C}\right]$ AF150(S) in rat are indicative of the potential of $\left[{ }^{11} \mathrm{C}\right]$ AF150(S) for specific labelling of M1ACh-R. However, PET studies in rat suffer from several limitations such as the difficulty of getting an arterial input function, the small brain regions and the resolution of the PET camera. Therefore, $\left[{ }^{11} \mathrm{C}\right] \mathrm{AF} 150(\mathrm{~S})$ should be further explored in PET studies in primates and humans. The chances of success and merit of such studies are supported by the following. M1ACh-R density in primate and human brain is about $50 \%$ higher than in rat brain, according to in vitro autoradiography studies [16]. No species differences in the binding affinity of compounds for M1ACh-R between various species including rat, primate and human have become apparent [59]; in this respect, it was found that the potency of AF150(S) to stimulate human M1ACh-R expressed in cells fully matches its binding affinity for M1ACh-R in rat brain homogenates (personal observations, manuscript in preparation). AF150 (S) shows a beneficial safety profile, and close congeners of AF150(S) have been in clinical studies and are being investigated as potential treatment (symptomatic and disease modification) for Alzheimer's disease [30].

\section{Conclusions}

The agonist radioligand $\left[{ }^{11} \mathrm{C}\right] \mathrm{AF} 150(\mathrm{~S})$ was rapidly taken up in the brain and showed fast kinetics with a significant M1ACh-R-related signal in brain areas that are rich in M1ACh-R. Moreover, binding of the agonist PET ligand $\left[{ }^{11} \mathrm{C}\right] \mathrm{AF} 150(\mathrm{~S})$ appears to be sensitive to changes in extracellular ACh levels. Further preclinical and clinical studies are needed to evaluate the full potential of $\left[{ }^{11} \mathrm{C}\right] \mathrm{AF} 150(\mathrm{~S})$ for imaging the active pool of M1ACh-R in vivo.

\section{Competing interests}

The authors declare that they have no competing interests.

\section{Authors' contributions}

HJCB performed the carbon-11 tracer synthesis and all animal studies. Data analysis and modelling were performed by HJCB, MCH and MY. Statistical analysis of the outcome measures was performed by HJCB and DLK. HJCB, ADW, MCH and JEL participated in the study design and discussion and interpretation of findings. HJCB drafted the manuscript. ADW, MCH, AF, JEL, and $A A L$ revised and gave advice for improvement of the manuscript. All authors read and approved the final manuscript.

\section{Acknowledgements}

This study was supported by a research grant from the A.J. Coops Foundation. Joost Verbeek, Dr. Koos (Jacobus) D.M. Herscheid, Rob P. Klok, Dr. Carla F.M. Molthoff, Saskia Berndsen, Maarten Schenke, Mariska Verlaan and Inge de Greeuw are acknowledged for their assistance with the animal handling. Dennis Laan, Rolph van Kooij, Arnold Spaans, Martien Mooijer and Pieter J. Klein are acknowledged for their assistance during the PET experiments and BV Cyclotron $\mathrm{VU}$ for providing the $\left[{ }^{11} \mathrm{C}\right] \mathrm{CO}_{2}$ and $\left[{ }^{18} \mathrm{~F}\right] \mathrm{F}^{-}$.

\section{Author details}

${ }^{1}$ Department of Nuclear Medicine \& PET Research, VU University Medical Center, PO Box 7057, Amsterdam, 1007 MB, The Netherlands. ${ }^{2}$ Department of Epidemiology and Biostatistics, VU University Medical Center, Amsterdam, 1007 MB, The Netherlands. ${ }^{3}$ Israel Institute for Biological Research, Ness-Ziona, Israel.

Received: 10 December 2012 Accepted: 7 March 2013

Published: 21 March 2013

\section{References}

1. Bartus RT: On neurodegenerative diseases, models, and treatment strategies: lessons learned and lessons forgotten a generation following the cholinergic hypothesis. Exp Neurol 2000, 163:495-529.

2. Caulfield MP: Muscarinic receptors - characterization, coupling and function. Pharmacol Ther 1993, 58:319-379.

3. Berstein G, Blank JL, Smrcka AV, Higashijima T, Sternweis PC, Exton JH, Ross EM: Reconstitution of agonist-stimulated phosphatidylinositol 4,5- 
bisphosphate hydrolysis using purified $\mathrm{m} 1$ muscarinic receptor, $\mathrm{Gq} / 11$, and phospholipase C-beta 1.J Biol Chem 1992, 267:8081-8088.

4. Mash DC, Potter LT: Autoradiographic localization of M1 and M2 muscarine receptors in the rat brain. Neuroscience 1986, 19:551-564.

5. Bymaster FP, Felder C, Ahmed S, McKinzie D: Muscarinic receptors as a target for drugs treating schizophrenia. Cur Drug Targets-CNS Neurol Disord 2002, 1:163-181

6. Bymaster FP, Whitesitt CA, Shannon HE, DeLapp N, Ward JS, Calligaro DO, Shipley LA, BuelkeSam JL, Bodick NC, Farde L, Sheardown MJ, Olesen PH, Hansen KT, Suzdak PD, Swedberg MDB, Sauerberg P, Mitch CH: Xanomeline: a selective muscarinic agonist for the treatment of Alzheimer's disease. Drug Dev Res 1997, 40:158-170.

7. Mirza NR, Peters D, Sparks RG: Xanomeline and the antipsychotic potential of muscarinic receptor subtype selective agonists. CNS Drug Rev 2003, 9:159-186.

8. Bodick NC, Offen WW, Levey Al, Cutler NR, Gauthier SG, Satlin A, Shannon HE, Tollefson GD, Rasmussen K, Bymaster FP, Hurley DJ, Potter WZ, Paul SM: Effects of xanomeline, a selective muscarinic receptor agonist, on cognitive function and behavioral symptoms in Alzheimer disease. Arch Neurol 1997, 54:465-473.

9. Vora MM, Finn RD, Boothe TE, Liskwosky DR, Potter LT: [N-methyl-C-11]scopolamine: synthesis and distribution in rat brain. J Labelled Comp Radiopharm 1983, 20:1229-1236.

10. Mulholland GK, Kilbourn MR, Sherman P, Carey JE, Frey KA, Koeppe RA, Kuhl DE: Synthesis, in vivo biodistribution and dosimetry of $\left[{ }^{11} \mathrm{C}\right] \mathrm{N}$ methylpiperidyl benzilate ([11C]NMPB), a muscarinic acetylcholine receptor antagonist. Nuc Med Biol 1995, 22:13-17.

11. Dewey SL, Macgregor RR, Brodie JD, Bendriem B, King PT, Volkow ND, Schlyer DJ, Fowler JS, Wolf AP, Gatley SJ, Hitzemann R: Mapping muscarinic receptors in human and baboon brain using [N-C-11-methyl]benztropine. Synapse 1990, 5:213-223.

12. Varastet M, Brouillet E, Chavoix C, Prenant C, Crouzel C, Stulzaft O, Bottlaender M, Cayla J, Mazière B, Mazière M: In vivo visualization of central muscarinic receptors using $\left[{ }^{11} C\right]$ quinuclidinyl benzilate and positron emission tomography in baboons. Eur J Pharmacol 1992, 213:275-284.

13. Zubieta JK, Koeppe AR, Frey KA, Kilbourn MR, Mangner TJ, Foster NL, Kuhl DE: Assessment of muscarinic receptor concentrations in affinity and Alzheimer disease with [C-11]NMPB and PET. Synapse 2001, 39:275-287.

14. McPherson W: Targeting cerebral muscarinic acetylcholine receptors with radioligands for diagnostic nuclear medicine studies. In Ion Channel Localization: Methods and Protocols. Edited by Lopatin AN, Nichols CG. Totowa (New York): Humana; 2001:17-38.

15. Christopoulos A, Kenakin T: G protein-coupled receptor allosterism and complexing. Pharmacol Rev 2002, 54:323-374.

16. Flynn DD, Mash DC: Distinct kinetic binding-properties of $\mathrm{N}-[\mathrm{H}-3]-$ methylscopolamine afford differential labeling and localization of M1 $M 2$, and M3-muscarinic receptor subtypes in primate brain. Synapse 1993, 14:283-296.

17. Potter LT, Ferrendelli CA, Hanchett HE: Two affinity states of M1 muscarine receptors. Cell Mol Neurobiol 1988, 8:181-191.

18. Ginovart N, Galineau L, Willeit M, Mizrahi R, Bloomfield PM, Seeman P, Houle S, Kapur S, Wilson AA: Binding characteristics and sensitivity to endogenous dopamine of [C-11]-(+)-PHNO, a new agonist radiotracer for imaging the high-affinity state of $D-2$ receptors in vivo using positron emission tomography. J Neurochem 2006, 97:1089-1103.

19. Finnema SJ, Seneca N, Farde L, Shchukin E, Sovago J, Gulyas B, Wikström $H V$, Innis RB, Neumeyer JL, Halldin C: A preliminary PET evaluation of the new dopamine D-2 receptor agonist [C-11]MNPA in cynomolgus monkey. Nuc Med Biol 2005, 32:353-360.

20. Mukherjee J, Narayanan TK, Christian BT, Shi BZ, Yang ZY: Binding characteristics of high-affinity dopamine D2/D3 receptor agonists, C-11 -PPHT and C-11-ZYY-339 in rodents and imaging in non-human primates by PET. Synapse 2004, 54:83-91.

21. Shi B, Narayanan TK, Christian BT, Chattopadhyay S, Mukherjee J: Synthesis and biological evaluation of the binding of dopamine D2/D3 receptor agonist, (R, S)-5-hydroxy-2-(N-propyl-N-(5'-18F-fluoropentyl)aminotetralin (18F-5-OH-FPPAT) in rodents and nonhuman primates. Nuc Med Biol 2004, 31:303-311.

22. Wilson AA, McCormick P, Kapur S, Willeit M, Garcia A, Hussey D, Houle S, Seeman $\mathrm{P}$, Ginovart N: Radiosynthesis and evaluation of $\left[{ }^{11} \mathrm{C}\right]-(+)-4-$ propyl-3,4,4a,5,6,10b-hexahydro-2H-naphtho[1,2-b][1,4]oxazin-9-ol as a potential radiotracer for in vivo imaging of the dopamine D2 highaffinity state with positron emission tomography. J Med Chem 2005, 48:4153-4160.

23. Frost JJ, Wagner HNJ, Dannals RF, Ravert HT, Links JM, Wilson AA, Burns HD, Wong DF, McPherson RW, Rosenbaum AE, Kuhar MJ, Snyder SH: Imaging opiate receptors in the human brain by positron tomography. J Comp Ass Tomogr 1985, 9:231-236.

24. Farde L, Suhara T, Halldin C, Nyback H, Nakashima Y, Swahn CG, Karlsson P, Ginovart N, Bymaster FP, Shannon HE, Foged C, Suzdak PD, Sauerberg P: PET study of the $\mathrm{M}(1)$-agonists [C-11]xanomeline and [C-11]butylthioTZTP in monkey and man. Dementia 1996, 7:187-195.

25. Fisher A, Heldman E, Gurwitz D, Haring R, Meshulam H, Brandeis R, Sapir M, Marciano D, Barak D, Vogel Z, Karton Y: AF150(S) and AF151(S): new M1 agonists mediate $\mathrm{m} 1$ selective signaling, neurotrophic-like effects and restore AF64A cognitive deficits in rats [abstract]. Soc Neurosci Abstr 1993, 19:1767.

26. Fisher A, Bar-Ner N, Karton Y: Methods and compositions for treatment of central and peripheral nervous system disorders and novel compounds useful therefore. 2003 (patent: WO 03/092580 A2).

27. Brandeis R, Sapir M, Hafif N, Abraham S, Oz N, Stein E, Fisher A: AF150(S): a new functionally selective $\mathrm{M} 1$ agonist improves cognitive performance in rats. Pharmacol Biochem Behav 1995, 51:667-674.

28. Beach TG, Walker DG, Potter PE, Sue LI, Fisher A: Reduction of cerebrospinal fluid amyloid $\beta$ after systemic administration of $\mathrm{M} 1$ muscarinic agonists. Brain Res 2001, 905:220-223.

29. Fisher A, Brandeis R, Bar-Ner R, Kliger-Spatz M, Natan N, Sonego H, Marcovitch I, Pittel Z: AF150(S) and AF267B, M1 muscarinic agonists as innovative therapies for Alzheimer's disease. J Mol Neurosci 2002, 19:145-153.

30. Fisher A: Cholinergic modulation of amyloid precursor protein processing with emphasis on M1 muscarinic receptor: perspectives and challenges in treatment of Alzheimer's disease. J Neurochem 2012, 120:22-33.

31. Buiter HJC, Leysen JE, Schuit RC, Fisher A, Lammertsma AA, Windhorst AD: Radiosynthesis and biological evaluation of the M1 muscarinic acetylcholine receptor agonist ligand [11C]AF150(S). J Labelled Comp Radiopharm 2012, 55:264-273.

32. Czernin J, Satyamurthy N, Schiepers C: Molecular mechanisms of bone ${ }^{18} \mathrm{~F}$ NaF deposition. J Nucl Med 2010, 51:1826-1829.

33. De Jong HWAM, van Velden FHP, Kloet RW, Buijs FL, Boellaard R, Lammertsma AA: Performance evaluation of the ECAT HRRT: an LSOLYSO double layer high resolution, high sensitivity scanner. Phys Med Biol 2007, 52:1505-1526.

34. Van Velden FHP, Kloet RW, van Berckel BNM, Lammertsma AA, Boellaard R: Accuracy of 3-dimensional reconstruction algorithms for the highresolution research tomograph. J Nucl Med 2009, 50:72-80.

35. Shannon HE, Rasmussen K, Bymaster FP, Hart JC, Peters SC, Swedberg MDB, Jeppesen L, Sheardown MJ, Sauerberg P, Fink-Jensen A: Xanomeline, an M1/M4 preferring muscarinic cholinergic receptor agonist, produces antipsychotic-like activity in rats and mice. Schizophr Res 2000 42:249-259

36. Watson M, Yamamura HI, Roeske WR: A unique regulatory profile and regional distribution of $\left[{ }^{3} \mathrm{H}\right]$ pirenzepine binding in the rat provide evidence for distinct M1 and M2 muscarinic receptor subtypes. Life Sci 1983, 32:3001-3011.

37. Hudkins RL, DeHaven-Hudkins DL: M1 muscarinic antagonists interact with sigma recognition sites. Life Sci 1991, 49:1229-1235. Life Sci 1992, 50:245. Erratum

38. Maruyama S, Tsukada H, Nishiyama S, Kakiuchi T, Fukumoto D, Oku N, Yamada S: In vivo quantitative autoradiographic analysis of brain muscarinic receptor occupancy by antimuscarinic agents for overactive bladder treatment. J Pharmacol Exp Ther 2008, 325:774-781.

39. Su TP: Evidence for sigma opioid receptor: binding of $\left[^{3} \mathrm{H}\right] \mathrm{SKF}-10047$ to etorphine-inaccessible sites in guinea-pig brain. $J$ Pharmacol Exp Ther 1982, 223:284-290

40. Vannucchi MG, Scali C, Kopf SR, Pepeu G, Casamenti F: Selective muscarinic antagonists differentially affect in vivo acetylcholine release and memory performances of young and aged rats. Neuroscience 1997, 79:837-846

41. Wang RH, Bejar C, Weinstock M: Gender differences in the effect of rivastigmine on brain cholinesterase activity and cognitive function in rats. Neuropharmacology 2000, 39:497-506. 
42. Buiter HJC, van Velden FHP, Leysen JE, Fisher A, Windhorst AD, Lammertsma AA, Huisman MC: Reproducible analysis of rat brain PET studies using an additional $I^{18} \mathrm{~F}$ N NaF scan and an MR based ROI template. Mol Imaging: Int J; 2012.

43. Bergstrom M, Grahnen A, Langstrom B: Positron emission tomography microdosing: a new concept with application in tracer and early clinical drug development. Eur J Clin Pharmacol 2003, 59:357-366.

44. Lammertsma AA, Hume SP: Simplified reference tissue model for PET receptor studies. Neuroimage 1996, 4:153-158.

45. Jakubik J, Michal P, Machova E, Dolezal V: Importance and prospects for design of selective muscarinic agonists. Physiol Res 2008, 57:S39-S47.

46. Machova E, El-Fakahany EE, Dolezal V: Xanomeline quasi-irreversibly bound to an ectopic site can stimulate presynaptic $M 2$ receptors via the orthosteric binding site. J Neurochem 2005, 94:90.

47. Oki T, Takagi Y, Inagaki S, Taketo MM, Manabe T, Matsui M, Yamada S: Quantitative analysis of binding parameters of $[3 \mathrm{H}] \mathrm{N}$-methylscopolamine in central nervous system of muscarinic acetylcholine receptor knockout mice. Mol Brain Res 2005, 133:6-11.

48. Tzavara ET, Bymaster FP, Felder CC, Wade M, Gomeza J, Wess J, McKinzie DL, Nomikos GG: Dysregulated hippocampal acetylcholine neurotransmission and impaired cognition in M2, M4 and M2//M4 muscarinic receptor knockout mice. Mol Psychiatry 2003, 8:673-679.

49. Flynn DD, Reever CM, FerrariDiLeo G: Pharmacological strategies to selectively label and localize muscarinic receptor subtypes. Drug Dev Res 1997, 40:104-116.

50. Saller CF, Czupryna MJ, Salama Al: 5-Ht2 receptor blockade by Ici-169,369 and other $5-\mathrm{Ht} 2$ antagonists modulates the effects of D-2 dopamine receptor blockade. J Pharmacol Exp Ther 1990, 253:1162-1170.

51. Damsma G, De Boer P, Westerink BHC, Fibiger HC: Dopaminergic regulation of striatal cholinergic interneurons: an in vivo microdialysis study. Naunyn Schmiedebergs Arch Pharmacol 1990, 342:523-527.

52. DeBoer $P, A$ Abercrombie ED: Physiological release of striatal acetylcholine in vivo: modulation by D1 and D2 dopamine receptor subtypes. J Pharmacol Exp Ther 1996, 277:775-783.

53. Billard W, Binch $\mathrm{H}$, Crosby G, McQuade RD: Identification of the primary muscarinic autoreceptor subtype in rat striatum as M2 through a correlation of in vivo microdialysis and in vitro receptor binding data. J Pharmacol Exp Ther 1995, 273:273-279.

54. Hume SP, Opacka-Juffry J, Myers R, Ahier RG, Ashworth S, Brooks DJ, Lammertsma AA: Effect of L-dopa and 6-hydroxydopamine lesioning on $\left[{ }^{11} \mathrm{C}\right]$ raclopride binding in rat striatum, quantified using PET. Synapse 1995, 21:45-53.

55. Hwang DR, Narendran R, Laruelle M: Positron-labeled dopamine agonists for probing the high affinity states of dopamine subtype 2 receptors. Bioconj Chem 2005, 16:27-31.

56. Narendran R, Mason NS, Laymon CM, Lopresti BJ, Velasquez ND, May MA, Kendro S, Martinez D, Mathis CA, Frankle WG: A comparative evaluation of the dopamine $\mathrm{D}(2 / 3)$ agonist radiotracer $\left[{ }^{11} \mathrm{C}\right](-)-\mathrm{N}$-propylnorapomorphine and antagonist $\left[{ }^{11} \mathrm{C}\right]$ raclopride to measure amphetamine-induced dopamine release in the human striatum. J Pharmacol Exp Ther 2010, 333:533-539.

57. Seneca N, Finnema SJ, Farde L, Gulyas B, Wikström HV, Halldin C, Innis RB: Effect of amphetamine on dopamine D2 receptor binding in nonhuman primate brain: a comparison of the agonist radioligand $\left[{ }^{11} \mathrm{C}\right] \mathrm{MNPA}$ and antagonist [C-11]raclopride. Synapse 2006, 59:260-269.

58. Hall JM, Caulfield MP, Watson SP, Guard S: Receptor subtypes or species homologs - relevance to drug discovery. Trend Pharmacol Sci 1993, $14: 376-383$

doi:10.1186/2191-219X-3-19

Cite this article as: Buiter et al:: $\left[{ }^{11} \mathrm{C}\right] \mathrm{AF} 150(\mathrm{~S})$, an agonist PET ligand for M1 muscarinic acetylcholine receptors. EJNMMI Research 2013 3:19.

\section{Submit your manuscript to a SpringerOpen ${ }^{\circ}$ journal and benefit from:}

- Convenient online submission

- Rigorous peer review

- Immediate publication on acceptance

- Open access: articles freely available online

- High visibility within the field

- Retaining the copyright to your article

Submit your next manuscript at $>$ springeropen.com 